P.N. Fyman MD, J.R. Reynolds PHARM D, F. Moser MD, M. Avitable PHD, P.A. Casthely MD, K. Butt MD

\title{
Pharmacokinetics of sufentanil in patients undergoing renal transplantation
}

Renal failure and chronic haemodialysis are ofien associated with alterations in fluid status and plasma proteins. These changes, in turn, may result in pharmacokinetic alterations in affected patients. The purpose of this study was to investigate the pharmacokinetics of sufentanit in chronic renal faiture patients undergoing kidney transplantation. Ten male patients were studied. Following induction of anaesthesia each parient received sufentonil $2.0 \mu \mathrm{g} \cdot \mathrm{kg}^{-1} \mathrm{IV}$ with subsequent serial plasma sampling for drug measurement from one to 360 minutes. A biexponertial equation provided the best fit of the sufentanil concentration data with mean \pm SEM distribution (alpha) and elimination (beto) half-lives of $2.9 \pm 1.3$ and $176 \pm 87$ minues, respectively. The mean $V_{\mathrm{C}}$ and $V_{\text {a bea }}$ values were $0.15 \pm 0.05$ $L \cdot \mathrm{kg}^{-1}$ and $0.85=0.16 \mathrm{~L} \cdot \mathrm{kg}^{-1}$, respectively; plasma drug clearance was $11.5 \pm 3.7 \mathrm{ml} \cdot \mathrm{kg}^{-1} \cdot \mathrm{min}^{-1}$. Mean values for $\mathrm{K} 1 \mathrm{O}, \mathrm{K} / 2$ and $\mathrm{K} 2 \mathrm{l}$ were $0.15 \pm 0.06 \cdot \mathrm{min}^{-1}, 0.4 \pm 0.14 \cdot \mathrm{min}^{-1}$ and $0.1 \pm 0.04 \cdot$ mist $^{-1}$, respectively. With the exception of $V_{d}$ beta, these pharmacokinetic values are similar to those reported in previous studies in general surgical, elderly and burn patients. The Vd beta values observed in this study may have resulted from alterations in drug distribution or elimination following revascularization of the inplanted kidneys. Nevertheless, il appears that modification of sufentanil doses is unncecessary in chronic renal failure patients undergoing renal transplantation.

\section{Key words}

ANALGESICS, NARCOTIC: sufentanil; PHARMaCOKINETICS: sufentanil; SURGERY: renal transplantation.

From the Departments of Anesthesiology. Long Island Jewish Medical Center (PNF), Clinical Pharmacy, St. John's University College of Pharmacy, Jamaica, New York (JRR), Anesthesiology, Downstate Medical Center, Brooklyn, N.Y. (FM, MA, PAC) and Surgery, Downstate Medical Center (KB). Work performed at Downstate Medical Center ${ }_{r}$ Brooklyn, N.Y.

Address correspondence to: Dr. P.N. Fyman, Department of Anesthesiology, Long Island Jewish Medical Center, New Hyde Park, NY 11042.
Sufentanil is a new analogue of fentanyl which is approximately five to ten times more potent.' While its pharmacokinetics have been extensively studied in patients undergoing various surgical procedures, ${ }^{2}$ they have not been determined in patients undergoing renal transplantation. There are several characteristics in these patients which may be associated with pharmacokinetic alterations. These include plasma protein changes and consequent alterations in drug binding, ${ }^{3,4}$ intravascular and extravascular volume alterations, electrolyte abnormalities and other physiologic derangements induced by chronic renal failure and/or chronic haemodialysis. In light of these characteristics, this study was undertaken to define the pharmacokinetic profile of sufentanil during renal transplantation.

\section{Methods}

Ten patients scheduled for kidney transplantation were included in this study. All patients provided written informed consent and the study protocol was approved by the Human Investigations Committee. All patients wcre in chronic renal failure and were undergoing haemodialysis three times per week. None had a history of liver disease or congestive heart failure. Patients received a kidney transplant from a living related or a cadaveric donor. Premedication consisted of diazepam 5-10 mg PO approximately 90 minutes prior to surgery.

Upon arrival in the operating room a peripheral IV and a central venous line were inserted under local anaesthesia. General anaesthesia was induced with thiopentone 5-7 $\mathrm{mg} \cdot \mathrm{kg}^{-1} \mathrm{IV}$, while the patient was breathing 100 per cent oxygen. Tracheal intubation was facilitated by atracurium $0.4 \mathrm{mg} \cdot \mathrm{kg} \mathrm{IV}$. Anaesthesia was maintained with isoflurane $0.5-1.0$ per cent (inspired concentration), as needed and nitrous oxide:oxygen 50:50. When the blood pressure and pulse stabilized, sufentanil $2.0 \mu \mathrm{g} \cdot \mathrm{kg}^{-1}$ was administered through the peripheral IV over a ten second period. Blood samples for sufentanil assay were obtained from the central venous line at $1,3,5,7,10,15,20,30$, and 60 minutes and hourly for six hours after drug administration, and at extubation. Time from sufentanil administration until the patients were extubated was also recorded. 


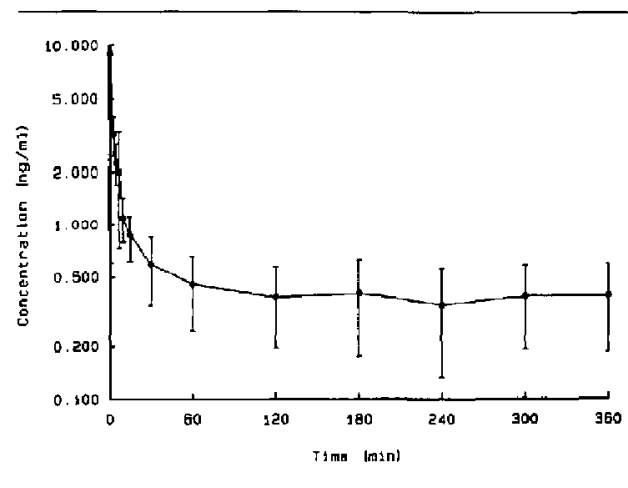

FIGURE Sufentanil plasma decay curve fitted to a tw0-compartment model. Times on horizonial axis refer to time after initial bolus. Conc $_{1}=10.5 \mathrm{e}^{-0.621 \mathrm{t}}+1.4 \mathrm{e}^{-0.025 \mathrm{t}}$

Plasma samples were separated and frozen until sufentanil plasma concentrations were measured using radioimmunoassay. A commercially available kit was used which had a sensitivity of $0.1 \mathrm{ng} \cdot \mathrm{ml}^{-1}$ and a variability of six to ten per cent. Tritium-labelled material was used for the assay. Plasma drug concentration vs time relationships for each patient were graphically fitted to both a bi- and triexponential equation using weighted, nonlinear least squares regression analysis. Results were expressed as mean \pm SEM. Derivations of pharmacokinetic parameters were in accordance with formulae described previously. ${ }^{5}$ Respiratory status was monitored by clinical observation. If respiratory rate was eight breaths $\mathrm{min}^{-1}$ or less the patient was considered to have respiratory depression.

\section{Resilts}

A total of ten patients were studied. All were on chronic dialysis prior to surgery. Seven patients received kidney transplants from living related donors and three from cadaveric donors. All patients were male. The mean age was $39 \pm 0.45$ years and mean weight was $67.5 \pm 1.3 \mathrm{~kg}$. Both bi- and triexponential equations described plasma decay curves well, with the biexponential equation providing the best fit. ${ }^{6}$ As seen in the Figure, initial plasma sufentanil concentrations decreased rapidly. After 30 minutes, the plasma decay of sufentanil occurred at a much slower rate. Approximately 180 minutes after sufentanil administration, a transient increase in plasma sufentanil concentration was noted in six of the ten patients. Beyond 180 minutes, elimination proceeded at an extremely slow rate. Pharmacokinetic data are listed in the Table. The mean $\pm S E M$ half lives for the alpha and beta phases were $2.9 \pm 1.3$ minutes and $176 \pm 87$ minutes, respectively. The volume of distribution in the
TABIE Pharmacokinctic data (mean \pm SEM)

\begin{tabular}{ll}
\hline$T_{1}$ alpha $(\mathrm{min})$ & $2.9 \pm 1.3$ \\
$T_{1}$ beta $(\mathrm{min})$ & $175 \pm 87$ \\
$V_{\mathrm{c}}\left(\mathrm{L} \cdot \mathrm{kg}^{-1}\right)$ & $0.15 \pm 0.05$ \\
$V d$ beta $\left(\mathrm{L} \cdot \mathrm{kg}^{-1}\right)$ & $0.85 \pm 0.16$ \\
Clearance $\left(\mathrm{ml} \cdot \mathrm{kg}^{-1} \cdot \mathrm{min}^{-1}\right)$ & $11.5 \pm 3.7$ \\
$\mathrm{~K} 10\left(\cdot \mathrm{min}^{-1}\right)$ & $0.15 \pm 0.05$ \\
$\mathrm{~K} 12\left(\cdot \mathrm{min}^{-1}\right)$ & $0.4 \pm 0.14$ \\
$\mathrm{~K} 2 \mathrm{I}\left(\cdot \mathrm{min}^{-1}\right)$ & $0.1 \pm 0.04$ \\
\hline
\end{tabular}

central compartment (Vc) was $0.15 \pm 0.05 \mathrm{~L} \cdot \mathrm{kg}^{-1}$ volume of distribution (Vd beta) was $0.85 \pm 0.16 \mathrm{~L} \cdot \mathrm{kg}^{-1}$ and total plasma clearance (CL) was $11.5 \pm 3.7 \mathrm{ml} \cdot \mathrm{kg}^{-1}$. $\min ^{-1}$. Transfer rate constants were: $\mathrm{K} 10=0.15 \pm$ $0.06 \cdot \mathrm{min}^{-1}, \mathrm{~K} 12=0.4 \pm 0.14 \cdot \mathrm{min}^{-1}$, and $\mathrm{K} 21=0.1 \pm$ $0.04 \cdot \min ^{-1}$.

Average duration of surgery was $165 \pm 32$ minutes. The duration of intubation was $235 \pm 113$ minutes. Plasma sufentanil concentration at extubation was $0.36 \pm$ $0.06 \mathrm{ng} \cdot \mathrm{ml}^{-1}$. Only one patient experienced prolonged respiratory depression, with a respiratory rate less than $8 \cdot \mathrm{min}^{-1}$ for nine hours. Beyond nine hours it increased to $8-10 \cdot \mathrm{min}^{-1}$. This patient's sufentanil plasma concentration was $0.4 \mathrm{ng} \cdot \mathrm{ml}^{-1}$ at the completion of surgery. The volume of fluids infused intraoperatively was $5.1 \pm 0.45 \mathrm{~L}$. All transplants functioned for at least 48 hours postoperatively.

\section{Discussion}

The pharmacokinetic data for each patient were best described using a biexponential equation. This is in agreement with sufentanil pharmacokinetic data reported in elderly patients ${ }^{7}$ and burn patients. ${ }^{8}$ However, another group of investigators found that a triexponential equation provided the best fit for sufentanil data in healthy surgical patients undergoing various surgical procedures. ${ }^{2}$

There are several factors which may explain why a two-compartment model best accommodated the data in this study and a three-compartment model best fit the data in normal patients. Organ perfusion, volume status and drug protein binding are important determinants of drug distribution and elimination. In renal failure patients each of these can be markedly altered. For instance, lack of kidney perfusion may decrease volume of distribution. Volume status is also greatly modified by haemodialysis and anuric renal failure. Depending on how recently dialysis occurred, patients may be either hypovolaemic or overhydrated.

Various studies have documented abnormal protein binding in uremic patients. ${ }^{9,10}$ There is evidence to suggest that these abnormalities are due, at lcast in part, to a qualitative defect rather than a quantitarive defect in plasma proteins. ${ }^{11-13}$ The pharmacokinetic alterations 
attendant to these abnormalities in renal failure patients may explain why sufentanil pharmacokinetics fit best to a biexponential curve. Nevertheless, central compartment volume of distribution (Vc), the terminal elimination half life and total drug clearance in our patients were almost identical to the values reported for healthy patients where the triexponential expression was employed. ${ }^{2}$ The volume of distribution (Vd beta), however, was much smaller in our study and was the only parameter which was substantially different from values derived in previous sufentanil studies. ${ }^{2,7,8}$ It is likely that this Vd beta difference resulted from the transient increase in sufentanil concentrations that occurred in many patients close to the time of revascularization of the implanted kidney and reperfusion of the lower extremity. Sufentanil which had been deposited in the legs may have been "washed" back into the circulation. The equation used to generate the $\mathrm{Vd}$ beta value depends on the terminal elimination slope (i.e., beta), which was influenced by the sudden, although slight, increase in the sufentanil concentration. Also, with reference to the terminal exponential function, apparent plasma sufentanil concentration decay was extremely slow. This may be attributed to the relatively short sampling time. Additional points beyond 360 minutes may have resulted in a better characterization of elimination.

Prolonged respiratory depression occurred in only one out of ten patients and this lasted for nine hours. In view of miotic pupils and the fact that adequate neuromuscular transmission was present as assessed by a nerve stimulator, sufentanil was the most likely cause of this respiratory depression. However, it is possible that isoflurane was a contributing factor. All other patients were extubated within approximately 45 minutes after arrival in the Recovery Ronm. None of the patients received an opioid antagonist or required reintubation. Although we did not have a control group to compare the duration of sufentanilassociated respiratory depression, clinically this was not a problem. This is further emphasized by the fact that virually all patients received low concentrations of isuflurane, an agent which may have potentiated narcoticinduced hypotension.

In conclusion, sufentanil pharmacokinetics in patients undergoing renal transplantation are similar to those reported in healthy patients. This suggests that the kidney plays little, if any, role in the drug's distribution and elimination. Accorcingly, adjustments in sufentanil doses appear to be unnecessary when anaesthetizing renal transplant patients. Since these patients had functioning kidneys for the latter part of the study, it should be emphasized that these findings may not apply to patients with renal failure that is not remedied.

\section{Acknowledgements}

We thank Ms. Ellen L. Jackson for manuscript preparation and W. Mechlinski, Ph.D. of Jannsen Pharmaceutica for performing the sufentanil assays.

\section{Re广erences}

1 Rolly $G$, Kay $B$, Cockx $F$. A double-blind comparison of high doses of fentanyl and sufentanil in man. Acta Anaesthesiol Belg 1979; 30: 246-7.

2 Bovill JG, Sebel PS, Blackburn CL, Oei-Lim V. Heykants $J J$. The phamacokinetics of sufentanit in surgical patients. Anesthesiology 1984; 61: 502-6.

3 Sjoholm I, Kober A, Odar-Cederlof I, Borja O. Protein binding of drugs in uremic and normal serum. The role of endogenous binding inhibitors. Biochem Pharmacol 1976; $1205-13$.

4 Pinfsky KM. Disease-induced changes in the plasma binding of basic drugs. Clin Pharmacokinet 1980; 5 : 246-62.

5 Gibaldi $M$, Perrier D. Phamacokinetics. 2nd ed. New York: Marcel Dekker Inc., 1982.

6 Boxenbaum HG, Riegelman $S$, Elashoff RM. Statistic5 estimations in pharmacokinetics. J Pharmacokin Biopharm 1974; 2: 123-48.

7 Malteo RS, Ornstein E, Young WL, Schwartz AE, Port M, Chang WJ. Phamacokinetics of sufentanil in the elderly. Anesth Analg 1986; 65: $\$ 94$.

8 Gregoretti $S$, Vinik $H R$. Sufentanil pharmacokinetics in burn patients undergoing skin grafting. Anesth Analg 1986; 65: $\$ 64$.

9 Olsen GG, Benett WM, Porter GA. Morphine and phenyroin binding to plasma proteins in renal and hepatic failure. Clin Pharmacol Ther 1975; 17: 677-84.

10 Piafsky $K M$. Disease-induced changes in the plasma binding of basic drugs. Clin Pharmacokinct 1980;5:246-62.

11 Boobis SW. Alteration of plasma albumin in relation to decreased drug binding in uremua. Clin Phurnacol Ther 1977; 22: 147-53.

12 Lunde PKM, Rave A. Yaffe SJ, Lunde L. Sjoquist F Plasma protein binding of diphenylhydantoin in man. Clin Pharmacol Ther 1970: 11: 846-55.

13 Shoeman DW. Berjamin DW, Azasnoff $D L$. The alteration of plasma proteins in uremia as reflected in the ability to bind diphenylhydantoin. Ann NY Acad Sci 1973; 226: $127-30$. 


\section{Rósumé}

L'insuffisance rénale et l'hémodialyse chronique gont souvent associés a des altérations de l'equilibre hydrique et des protéines plasmatiques. Ces changements peuvent à leur tour anener des altérations pharmacocinétiques chez les patients affectés. Le but de cette étude était d'investiguer la pharmacocinétique du sufentanil chez les patients en insuffisance rénale chronique devant subir une greffe rénale. Dix patients mâles ont ète étudiés. Suivant I' induction de l'anesthésie chague patient a reçu du sufentanil $2.0 \mathrm{\mu g} \cdot \mathrm{kg}^{-1}$ par voie intraveineuse avec un échantillonnage sérié subséquent du plasma pour la mesure des médicaments de 0 à 360 minutes. La courbe la plus appropriée pour la concentration de sufentanil était une courbe représentée par une expression biexponentielle, la moyenne $\pm S E M$ de la demi-vie de distribution (alpha) et délimination (beta) êtait respectivement $2.9 \pm 1.3$ et $176 \pm 87$ minutes. La Vc moyenne et le $V d$ beta étaient de $0.15 \pm 0.05 \mathrm{~L} \cdot \mathrm{kg}^{-1}$ et $0.85 \pm 0.16$ $L \cdot \mathrm{kg}^{-1}$ respectivement. La clearance plasmatique de la drogue était de $11.5 \pm 3.7 \mathrm{ml} \cdot \mathrm{kg}^{-1} \cdot \mathrm{min}^{-1}$. Les valeurs moyennes de K10, K12 et K21 étaient de $0.15 \pm 0.06 \cdot \mathrm{min}^{-1}, 0.4 \pm$ $0.14 \cdot \mathrm{min}^{-1}$ et $0.1 \pm 0.04 \cdot \mathrm{min}^{-1}$, respectivement. A l'exception de Vd beta, ces valeurs pharmacocinétiques étaient similaires à celles rapportées dans d'autres études en chirurgie générale chez les patients brâlés et des gens ágés. La valeur Vd beta observée dans cetre étude peut résulter des altérations de la distribution de la drogue ou de lelimination suite à la revascularisation du rein yreffé. II apparait néanmoins que les modifications de la dose de sufentanil n'est pas nécessaire chez Les patients en insuffisance rénale chronique devant subir une greffe rénale. 